\title{
Public debt, budget deficit and tax policy reforms for fiscal consolidation in Sri Lanka: rationale and feasibility
}

\author{
Thanabalasingam Vinayagathasan* and Jothiratne Ganithage Sri Ranjith \\ Department of Economics and Statistics, Faculty of Arts, University of Peradeniya, Peradeniya, Sri Lanka.
}

\begin{abstract}
This paper aims to examine the rationale and feasibility to minimise the budget deficit that maintains the public debt at manageable level without retarding economic growth. Accumulation of government debt may subsequently shape future budget deficit via policies aimed at deficit reduction. Government authorities substantiate austerity and deficit reduction arguing for a case of sustainable fiscal policy. Hence, this study investigates the relationship between public debt, budget deficit and tax policy reforms for fiscal consolidation in Sri Lanka for the period 1990-2019. The study found that direct tax revenue, indirect tax revenue, real GDP and consumer price index are negatively correlated with government debt to GDP ratio in the long run, while in the short run, only direct tax revenue affects it significantly. Whereas, government expenditure, budget deficit, lending interest rate and exchange rate have positive and statistically significant impact on government debt to GDP ratio in the long run, while only exchange rate affects it significantly in the short run. This study identified unidirectional causality relationship between GE and PD, TRD and PD, TRID and PD, RGDP and TRD, RGDP and EXR, CPI and TRD, CPI and TRID and bilateral causality between RGDP and TRID. Findings of this study suggest that there is a rationale and feasibility to achieve fiscal consolidation in Sri Lanka by tax policy reforms and adjustments of government expenditures. The necessity of tax reforms is reflected by the greater potentials of direct taxes over the indirect taxes to contribute for public debt reduction, both in the short run and long run.
\end{abstract}

Keywords: Budget deficit, public debt, tax policy reforms, revenue-based fiscal consolidation.

\section{INTRODUCTION}

The recent budgetary outlook in Sri Lanka shows that there is a necessity to reduce traditionally maintained large fiscal deficit and keep up with good fiscalmonetary coordination to achieve development goals and sustainable growth. For this reason, currently fiscal policy is in the process of implementing a fiscal consolidation program. Fiscal consolidation generally refers to policy measures undertaken by governments to rectify fiscal imbalance or to stabilise the deficits that basically involves either spending cuts or increasing revenues (Kumarasiri et al., 2019; OECD, 2011).

Sri Lanka has chosen this strategy to face a major challenge to be confronted presently and ahead of time regarding the high and accumulation of public debt. The government debt to GDP ratio has increased to $86.8 \%$ at the end of 2019 , reflecting the impact of higher net borrowings to finance the enlarged budget deficit (Sri Lanka, Central Bank of Sri Lanka, 2019). Although the ratio of debt service payments (interest and amortization) to government revenue improved to $107 \%$ in 2019 from $108.8 \%$ in 2018 , the level of debt service payments which is in excess of the level of government revenue remained as a challenging and serious issue. Nevertheless, the sharp rise in government debt seems to underscore the importance of the fiscal consolidation measures and the impinging consequences

"Corresponding author (vinayagamkili@yahoo.com; (iD https://orcid.org/0000-0001-8043-5888)

This article is published under the Creative Commons CC-BY-ND License (http://creativecommons.org/licenses/ 
on the economy and society. The current level of public debt is absolutely high compared to the peer countries. For instance, according to recent figures of World Bank, many of the Asian countries maintain the public debt to GDP ratio around or below 50\%. Sri Lanka is seemingly far from debt sustainability and currently struggling to find the way out of high debt-low growth trap. Hence as empirical evidence shows, public debt beyond manageable level can have negative effects on economic activity (Coomaraswamy, 2017). The situation is further aggravated by persistent current account deficit of the balance of payments and lack of prudent foreign sources to borrow for servicing the international debt of the government. Therefore, reduction of public debt is critical to Sri Lankan economy as it is detrimental to budget deficit, fiscal flexibility, balance of payments, economic and financial sustainability.
Figures 1 and 2 depict the trend of debt and debt service payment ( $\%$ of GDP), tax revenue and budget deficit ( $\%$ of GDP), respectively, reflecting the problematic aspects of the fiscal and economic conditions of Sri Lanka since 1990 .

Figure 1 illustrates that even though debt to GDP ratio shows a downward sloping trend over the period of the study, it has small fluctuations, while debt service payment is almost the same during the whole period. The tax revenue fell gradually until 2012 and then it started to increase while budget deficit fluctuates moderately over the study period.

From economic development perspectives, fiscal policy does not seem to be effective for GDP growth and employment creation and thereby resulting low level of tax revenues (\% GDP). Furthermore, a greater percentage of total debt service to government revenue ratio is on

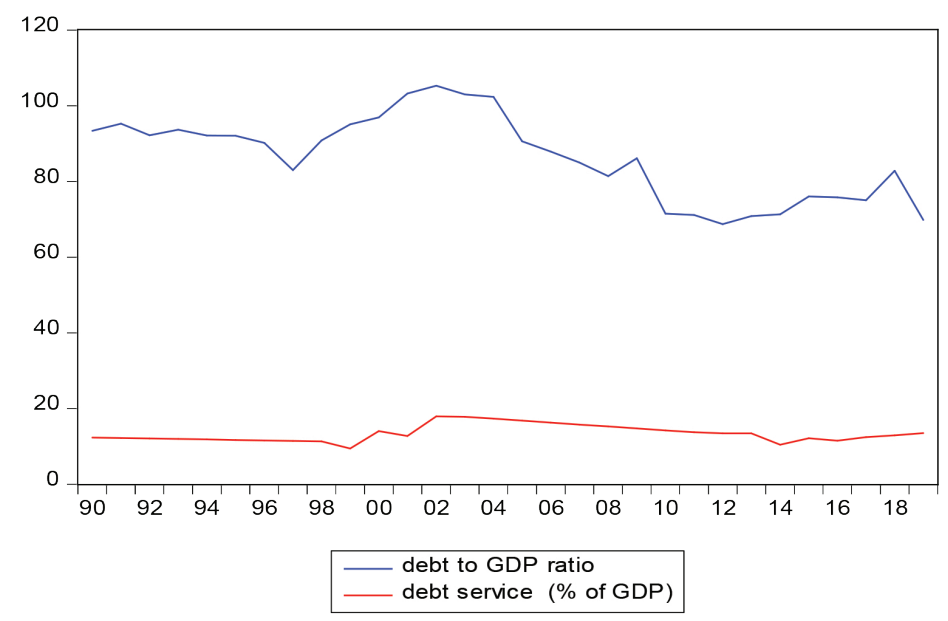

Figure 1: Trend of Debt and Debt service payment (\% of GDP) from 1990-2019

Source: Authors' calculation based on CBSL data

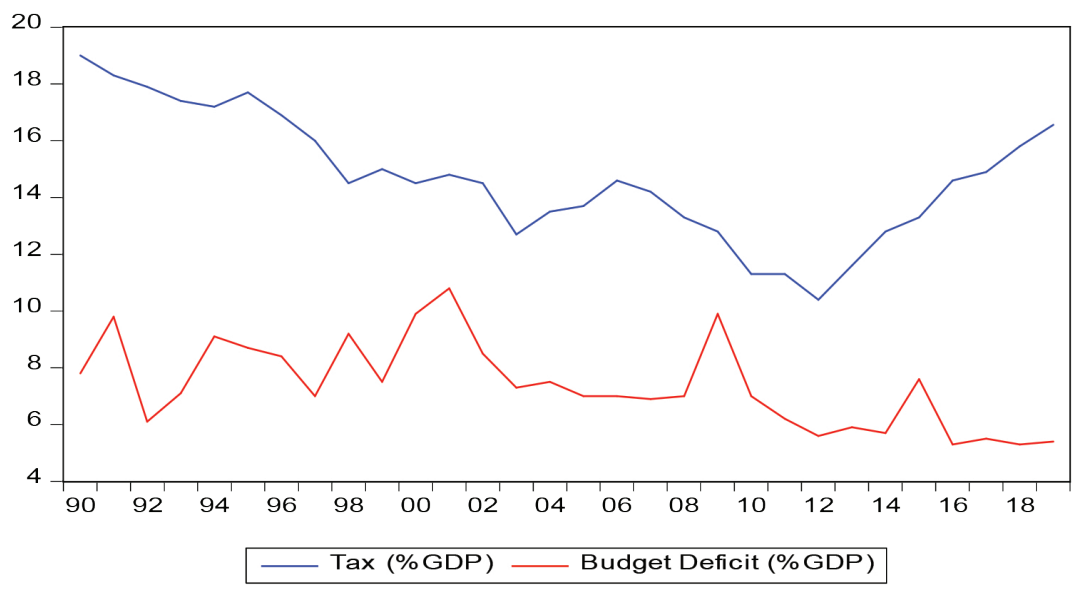

Figure 2: Trend of Tax and Budget Deficit (\% of GDP) from 1990-2019

Source: Authors' calculation based on CBSL data 
average around $90 \%$ over the last $5-10$ years period. Therefore, under the current situation, the Government is compelled to rollover accumulated debt as they mature, leaving economic growth related expenditures behind.

Having a persistent and relatively high fiscal deficit is detrimental to the economy in many dimensions. Mostly the negative impacts are resulted by creating inflationary pressure which causes severe hardships to fixed and lower wage earners, and higher wages will increase costs of production. This process would lead to erode the country's competitiveness in the foreign markets, loss of employment and lower foreign exchange incomes due to the reduction in exports earnings. Depreciation of currency, on the other hand, would be counter-cyclical through further inflation and low import elasticity. In addition, the political compulsions incurred by the elections of politicians to many government tiers increase public expenditures on popular measures such as salary increases, offering public sector employment, welfare programs and reduction or concessions of taxes to the corporate sector and consumer goods would disrupt fiscal disciplines and budgetary targets. Therefore, maintaining the fiscal deficit at a desirable as well as manageable level would be challenging but a paramount requirement at this juncture to minimise the adverse impact of large debt service cost, public expenditure priorities and shortage of funding available for investment and social infrastructure development and economic stability.

Considering the above scenario, the recent budgetary measures proposed to be aligned with revenue-based fiscal consolidation path for Sri Lanka. Although the Central Bank of Sri Lanka has made effort to curb credit growth and stabilise inflation while supportive Inland Revenue tax policy reforms being introduced, the economy still remains vulnerable to many adverse effects given the sizable public debt and large refinancing needs and low external buffers. Considering these aspects, IMF Country Report 2018 underscores that Sri Lanka needs robust implementation of New Inland Revenue Act of 2017 and continuously fine-tuning its public expenditure policy and mitigation of fiscal risk to support fiscal consolidation efforts (IMF, 2018). However, examining the empirical reasoning behind the factors that delaying or less likely to realise expected outcomes of policy reforms and adjustments remains as an important research problem.

Although there are much debates, discussions and economic and political ramifications over the feasibility of achieving the expected outcomes, still there has no adequate research been conducted systematically to understand the rationale and feasibility of realising the goals of fiscal consolidation process in Sri Lanka.
Therefore, this research aims to fill that research gap by assessing the feasibility of the revenue-based fiscal consolidation process to achieve the aforesaid fiscal sustainability and economic stability. Also the results of this study may help to revitalize the policy prescription to prevent further accumulation of public debt and find the way out of high-debt and low-growth trap.

\section{DETERMINANTS OF PUBLIC DEBT AND ITS IMPACT ON ECONOMIC GROWTH}

Public debt has been a much debated topic among economic researchers in recent years. The literature shows various determinants of public debt with different magnitude of their importance to economic growth (Sinha et al., 2011; Nguyen, 2015). The simple form of Keynesian school of thought provides theoretical justification for public debt as it expands the aggregate demand to boost the economy. Although there is no generally accepted rule for the sustainable level of debt in an economy, the fiscal policy becomes less effective as a countercyclical tool when the ratio of debt to GDP is exceeding around 60\% (Sinha et al., 2011; Lopes de Veiga et al., 2016). Ardagna (2001), using a dynamic general equilibrium model for OECD countries, shows that fiscal adjustments, implemented by cutting spending items increase households' welfare, are more effective in reducing the primary deficit and public debt than increasing tax rates.

These findings justify the relevance of government expenditures as a determinant of public debt. Extending this research further by incorporating more variables, Sinha et al. (2011) concludes that the GDP growth rate, being the most important determinant of the public debt and government expenditure, is also a significant determinant of public debt depending upon the country being a high income group country or not. However, the relationship between economic growth and public debt is negative and exhibits, from a given level of debt, an inverted $U$ shape behavior with regard to 52 African countries which indicates the limits of public debt for gaining favorable outcomes (Lopes de Veiga et al., 2016).

A similar result is shown in another study by Checherita \& Rother (2010), with reference to twelve euro area countries over a period of about 40 years, starting in 1970. They have found that there is a nonlinear impact of debt on growth with a turning point beyond which the public debt to GDP ratio has a negative impact on growth. The paper suggests that the negative growth effect of high debt may start from levels of around $70-80 \%$ of GDP. From policy perspectives, the results provide directions to debt reduction where public debt is no longer effective in making better prospects for long term economic growth. 
The literature further reveals that there is an inflationary effect of public debt. According to Lopes de Veiga et al. (2016), which shows that the relationship between public debt, economic growth and inflation in a group of 52 African economies between 1950 and 2012, the high levels of public debt are coincident with reduced rates of economic growth and rising levels of inflation. Nguyen (2015), with reference to developing countries, shows that public debt has a significantly positive effect on inflation while in the opposite direction, inflation has a significantly negative effect on public debt for the whole sample and three sub-samples. It means that in these developing countries, high public debt causes inflation, and high inflation could erode the real value of public debt. Also high inflation leads to increase debt burden and worsening the current account of the balance of payments.

Furthermore, the existing literature shows that the determinants of public debt have not been adequately studied for the South Asian countries including Sri Lanka. Also the findings of the conducted research may have contextual specifies particularly the countries with different development levels and regional variations. Hence, Sri Lanka can be considered as a special case that has experienced of chronic budget deficits, lowest tax-toGDP ratio and confronted with debt accumulation as well as high cost debt service payments (Coomaraswamy, 2017; IMF, 2018).

This research paper examines options for reducing domestic discretionary spending, pruning the defense budget, raising revenues and investing additional resources in human capital for realising long term sustainable growth with easing the debt accumulation issue. Nevertheless, expenditure cannot be reduced in priority sectors such as health, education and welfare programs etc.

\section{REVENUE-BASED FISCAL CONSOLIDATION}

Fiscal consolidation is generally defined as concrete policies aimed at reducing government deficits and debt accumulation (OECD, 2011). Fiscal consolidation has benefits of providing space to maintain low interest rate, stable inflation and thereby, boost the economy through private investment, and employment generation. The key approaches of fiscal consolidation involve either spending cuts or increased revenues to achieve fiscal sustainability. Many of the research in this regard discusses the expenditure-based, as well as revenuebased, policy measures interchangeably for fiscal consolidation. The literature on fiscal consolidation concurrently rationalises heterogeneous effects of spending versus revenue-based fiscal consolidation
(Alesina et al., 2017). The relative contribution of these two components and the ways in which such process is implemented, duration and the outcomes in a successful fiscal adjustment process is obscure and in most cases debatable (Kumarasiri et al., 2019; Coomaraswamy, 2017; Molnár, 2013). Furthermore, the appropriate amount of fiscal consolidation for each country will depend on a number of factors, including the strength of its economy, the public debt and interest developments, the ease of financing debt, and political decisions concerning taxes and spending (OECD, 2011: p. 17).

The theoretical underpinning here is that revenue hikes, in terms of taxation, is possible to impose an adverse impact on economic growth and result in larger output reductions, than both cuts in government spending and transfers. Alesina et al. (2017) rationalise this heterogeneity in a new-Keynesian model with persistent fiscal shocks, where the impact of persistent spending cuts on aggregate demand is mitigated by wealth effects (cited in Beetsma et al., 2018: p. 5). On the other hand, revenue-based consolidations can also be effective, if there is room to increase the revenue-toGDP ratio, in particular if the revenue types that are less harmful for growth (such as user fees, environmental taxes, property taxes and value-added taxes) are underexploited (Tsibouris et al., 2006). Furthermore, showing the components of revenue based measures, Alesina \& Perotti (1995) found that the small share of successful adjustments due to increases in tax revenues comes almost exclusively from corporate income taxes and not indirect taxes (cited in Molnár, 2013: p. 129). Therefore, the literature on fiscal consolidation shows that the outcomes of policy measures are rather mixed depending on various factors and effectiveness of policy measures that are mostly contextual.

According to Swati (2019) fiscal consolidation process in Sri Lanka has initially been successful in keeping up with the debt and deficit burden at a manageable level during 1991-2016. Nevertheless, tax revenues have declined to lower levels despite increase in per capita income in the last 10 years. Then possible option available to increase tax revenues is a tax policy reform to correct this anomaly. Budget proposals are already made for tax policy reforms (for example, $60 \%$ to $40 \%$ balance between indirect and direct taxes respectively, higher tax compliance, broadening tax base and rationalisation of the tax policy etc.). Also the Inland Revenue Act (IRA) was introduced in 2017, with the view of simplifying and modernising the IRA focusing on broadening the tax base by removing excessive tax incentives and expanding the sources of income; modernising rules related to cross-border transactions 
to address base erosion and combat tax avoidance; reducing complexity through an improved principlesbased drafting style; and strengthening and clarifying existing powers of the Inland revenue Department (IRD) to improve enforcement (IMF, 2018; Coomaraswamy, 2017).

However, the outcomes of these reforms are yet to be achieved and assessed. According to Kumarasiri et al., (2019), if the government expenditure remains same, the revenue based fiscal consolidation variables used in all models were significant with level of five percent and below. But the authors have not explored enough insights into how tax policy variables positively associate with expansionary impact on economic growth.

Hence, the current situation shows that Sri Lanka faces the challenge of rationalising government expenditure. Also, the country needs to enhance tax revenues through appropriate policy reforms. Can Sri Lanka achieve this goal and put the country's public finances back on track by implementing revenue-based fiscal consolidation process as a strategy? Does it have the potentials and feasibility? The authors' thinking is that this empirical question cannot be answered on the basis of theoretical implications only. Therefore, this study intends to answer these questions and make necessary policy recommendations by examining the impact of tax policy and budget deficit among other macroeconomic variables in the determination of public debt.

\section{DATA, VARIABLES AND METHODOLOGY}

This paper uses annual time series data for Sri Lanka over the period of 1990-2019 1 to examine the above mentioned objective. This study adopts public debt to GDP ratio (PD) as dependent variable and direct tax revenue (TRD), indirect tax revenue (TRID) as a proxy for tax policy reforms ${ }^{2}$ and overall budget deficit (BD), government expenditure (GE), real gross domestic product (RGDP), consumer price index (CPI) lending interest rate (LIR) and Exchange rate (EXR) as explanatory variables. Where PD, BD and GE are measured as a percentage of GDP; TRD and TRID are measured as a percentage of total revenue; CPI is measured in index $(2010=100)$; RGDP is measured in constant prices of 2010 US Dollar; LIR is the bank rate that meets the short-and mediumterm financing needs of the private sector measured as a percentage and ER is measured in period average of the ratio of local currency units per US Dollar. All the variables except interest rate were transformed into natural logarithm form. The data of RGDP, GE, CPI,
EXR, LIR, TRD and TRID are extracted from World Development Indicator of the World Bank data base, whereas PD and BD data are collected from Central Bank of Sri Lanka annual reports.

Following some of the empirical literature (e.g., Sinha et al., 2011), the authors modified and developed the long-run relationship between the variables, as Equation 1 below:

$$
\begin{aligned}
\ln \mathrm{PD}_{\mathrm{t}}= & \delta_{0}+\delta_{1} \ln \mathrm{RGDP}_{\mathrm{t}}+\delta_{2} \ln \mathrm{GE}_{\mathrm{t}}+\delta_{3} \ln \mathrm{TRD}_{\mathrm{t}} \\
& +\delta_{4} \ln \mathrm{TRID}_{\mathrm{t}}+\delta_{5} \ln \mathrm{CPI}_{\mathrm{t}}+\delta_{6} \ln \mathrm{BD}_{\mathrm{t}}+ \\
& \delta_{7} \mathrm{LIR}_{\mathrm{t}}+\delta_{8} \ln \mathrm{EXR}_{\mathrm{t}}+\varepsilon_{\mathrm{t}}
\end{aligned}
$$

Where, In represents the natural logarithm, names of variables are as explained earlier, $\varepsilon_{t}$ is the white noise error term and $t$ illustrate the time period.

The estimation of Equation (1) initiates with the identification of the order of integration of each variable using Augmented Dickey Fuller (ADF) and Philips-Perron (PP) unit root test for this analysis. The reason for using two approaches is to compare the results of ADF test with PP test to see whether the same conclusion is obtained or not. In the second step of the estimation procedure, the optimal lag length that can be used in the model had to be chosen. Because, the underlying theory and any hypothesised structure will indicate to the economist which variable is to be included in the model and how many lags would be appropriate. Therefore, the method of determining the appropriate lag length is still an important issue in the time series literature since longer lag lengths increase the number of estimated parameters, reduce degrees of freedom and increase data requirements. There have been several methods proposed to deal with the problem of correctly determining the proper lag length for time series model like Vector Autoregressive (VAR), Vector Error Correction Model (VECM) and Autoregressive Distributed Lag (ARDL) etc. There are several criteria such as sequentially modified Likelihood Ratio (LR) statistics, Akaike Information Criterion (AIC), Swartz Information Criterion (SC), Hannan-Quin Information Criterion (HQIC) and Final Prediction Error (FPE) to select the optimal lag length that can be included in a time series model. However, this study will adopt either one or more of these criteria in its analysis according to the results and the requirements.

Once the order of integration and the optimum lag length are confirmed, Johansen cointegration technique was applied to estimate Equation (1) in order to 
identify number of cointegrating equations and long run relationship between the variables. If at least one or more (k-1) cointegrating equations were detected, then there exist a long-run correlation between the variables and it is advised to compute the Error Correction Model (ECM) to identify the short run dynamic relationship and long run adjustment of the model. The ECM is given by Equation 2;

$$
\Delta \ln \mathrm{Y}_{\mathrm{t}}=\phi_{0}+\varphi \mathrm{ECT}_{\mathrm{t}-1}+\sum_{i=1}^{\mathrm{p}-1} \Gamma_{i}^{*} \Delta \ln \mathrm{Y}_{\mathrm{t}-i}+u_{t}
$$

where, $\ln \mathrm{Y}_{\mathrm{t}}=\left[\ln \mathrm{PD}_{\mathrm{t}}, \ln \mathrm{RGDP}_{\mathrm{t}}, \ln \mathrm{GE}_{\mathrm{t}}, \ln \mathrm{TRD}_{\mathrm{t}}, \ln \mathrm{TRID}_{\mathrm{t}}, \ln \mathrm{CPI}_{\mathrm{t}}\right.$, $\left.\ln \mathrm{BD}_{\mathrm{t}}, \mathrm{LIR}_{\mathrm{t}}, \ln \mathrm{EXR}_{\mathrm{t}}\right]^{\prime}$ vector of endogenous variables ${ }^{3}, \ln \mathrm{Y}_{\mathrm{t}-i}$ is the lagged value of the above variables, $\Delta$ denotes the first difference operator, $\varphi$ and the $\Gamma^{*}$ are functions of $\Gamma$ 's.

$$
\Gamma_{j}^{*}=-\sum_{i=j+1}^{\mathrm{p}} \Gamma_{i}, \mathrm{j}=1, \ldots, \mathrm{p}-1 ; \varphi=\left(\mathrm{I}-\Gamma_{1}-\ldots-\Gamma_{\mathrm{p}}\right)=-\Gamma(1) .
$$

If,$\varphi=0$ then there is no cointegration. If $\varphi$ has full rank, $K$, then the P's cannot be I(1) but are stationary and $\varphi=\alpha \beta^{\prime}$ where $\alpha$ is $(9 \times 1)$ vector of speed of adjustment coefficient, $\beta$ is the $(1 \times 9)$ vector of cointegrating coefficients and $u_{t}$ is the white noise error term.

Finally, the Granger causality test was employed to find out the causality relationship between the variables. The model is formed as in Equation 3 and 4.

$$
\begin{aligned}
\Delta \ln \mathrm{PD}_{\mathrm{t}} & =c_{1 \mathrm{t}}+\sum_{i=1}^{\mathrm{p}} \alpha_{i} \ln \Delta \mathrm{PD}_{\mathrm{t}-i} \\
& +\sum_{i=1}^{\mathrm{p}} \delta_{i} \Delta \ln \mathrm{BD}_{\mathrm{t}-i}+v_{1 \mathrm{t}} \\
\Delta l n \mathrm{BD}_{\mathrm{t}} & =c_{2 \mathrm{t}}+\sum_{i=1}^{\mathrm{p}} \pi_{i} \Delta \ln \mathrm{PD}_{\mathrm{t}-i} \\
& +\sum_{i=1}^{\mathrm{p}} \rho_{i} \Delta \ln \mathrm{BD}_{\mathrm{t}-i}+v_{2 \mathrm{t}}
\end{aligned}
$$

Using either F-test or Chi squared distribution, the following hypotheses were tested: for Equation (3): $\mathrm{H}_{0}$ : budget deficit does not granger causes public debt and for Equation (4): $\mathrm{H}_{0}$ : public debt does not granger causes budget deficit. $\mathrm{H}_{0}$ will be rejected when test statistic is greater than the critical value and conclude that budget deficit granger causes public debt in Equation (3) that is

$\sum_{i=1}^{\mathrm{p}} \delta_{i}$ is significant in Equation (3). And public debt granger causes budget deficit in Equation (4), that is

$\sum_{i=1}^{\mathrm{p}} \pi_{i}$ is significant in Equation (4). If both of these parameters are not significant then no causality exists between these two variables. Likewise we can do the test for all other variables that included in the model.

\section{RESULTS AND DISCUSSION}

\section{Descriptive analysis}

Figures 3 and 4 below show the relationship between PD and TRD, PD and TRID, respectively. As expected, the confidence ellipse in the Figure 3 shows the negative relationship between PD and TRD, whereas Figure 4

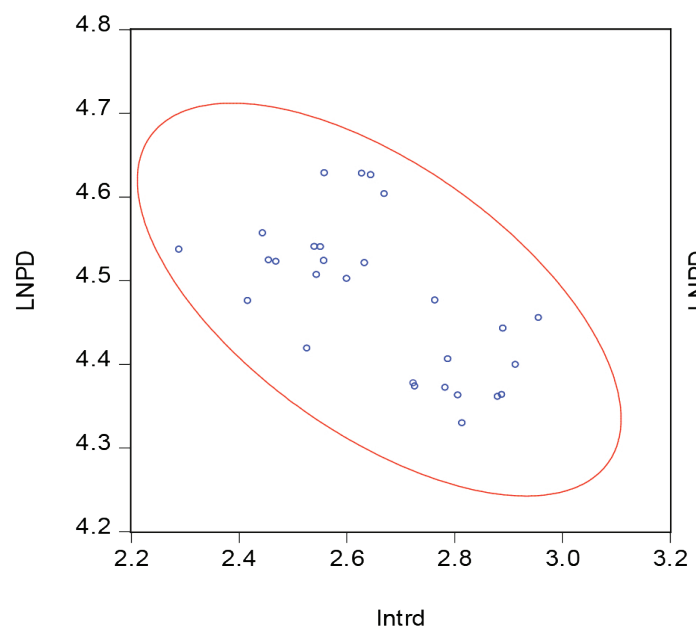

Figure 3: Relationship between PD and TRD

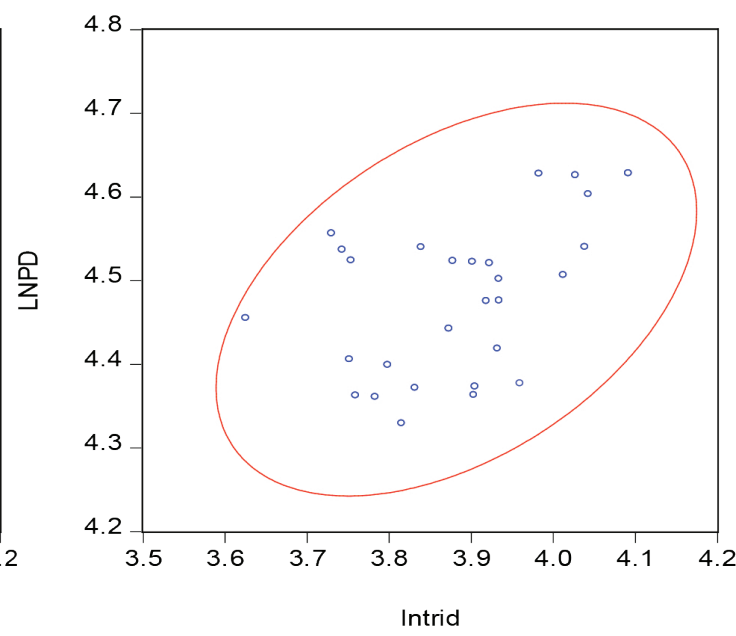

Figure 4: Relationship between PD and TRID

Source: Authors' calculation based on CBSL and WB data 


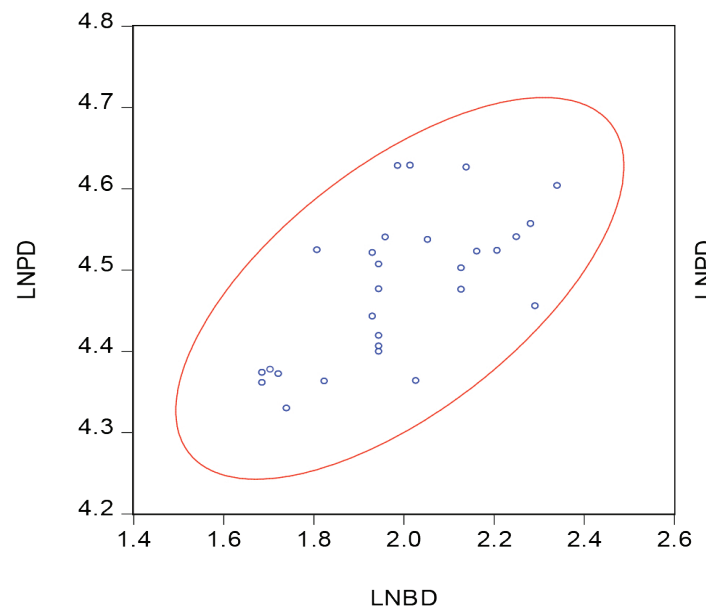

Figure 5: Relationship between $\mathrm{PD}$ and $\mathrm{BD}$

Source: Authors' calculation based on CBSL and WB data

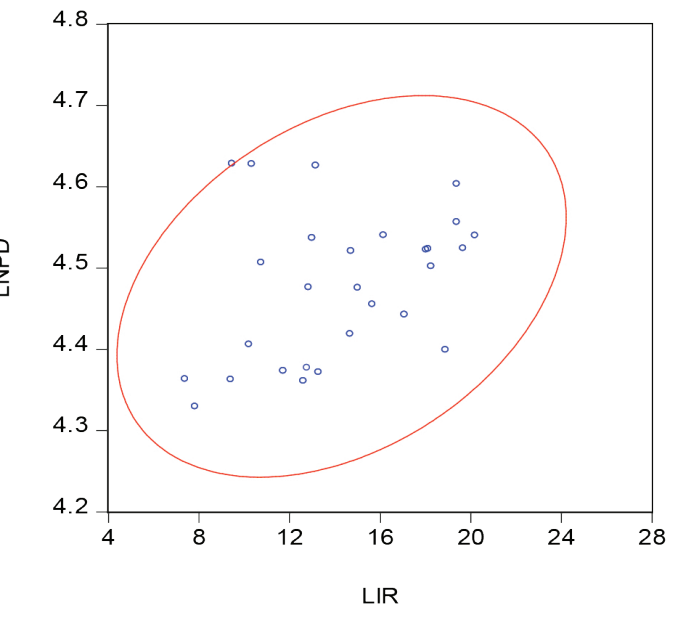

Figure 6: Relationship between PD and LIR

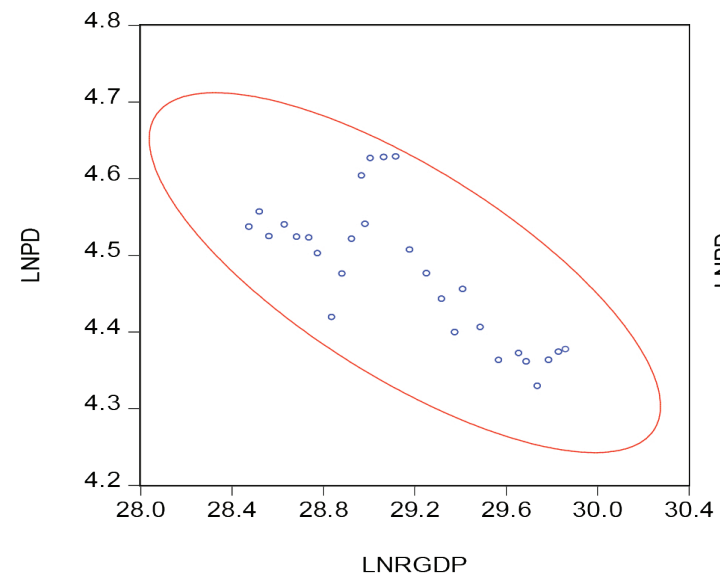

Figure 7: Relationship between PD and RGDP

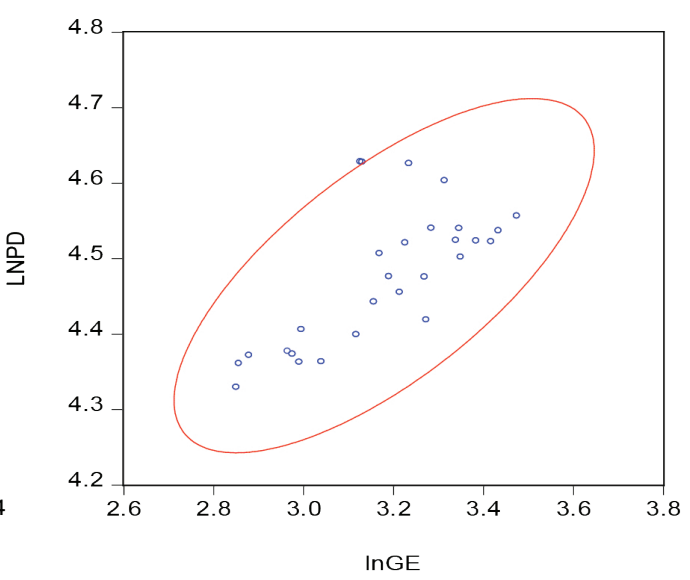

Figure 8: Relationship between PD and GE

Source: Authors' calculation based on CBSL and WB data

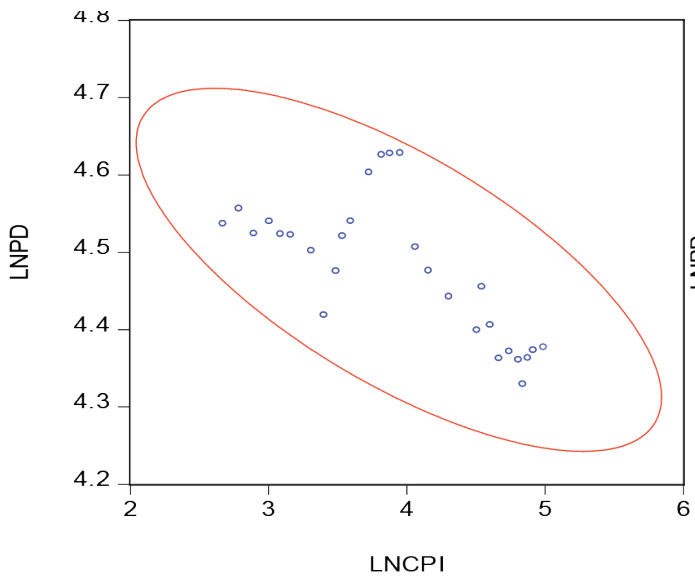

Figure 9: Relationship between PD and CPI

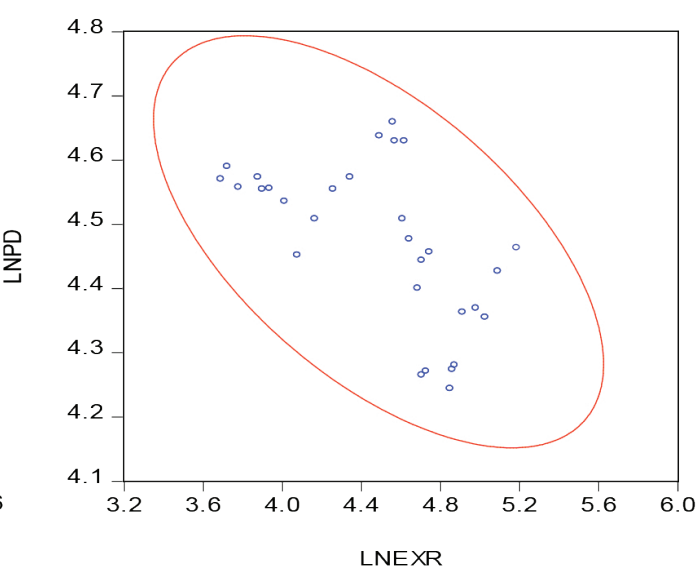

Figure 10: Relationship between PD and EXR

Source: Authors' calculation based on CBSL and WB data 
depicts a positive correlation between PD and TRID, which is in contrast with the expectation. However, this may not be a contradictory result due to lower probability indirect taxes have for immediate debt stabilization effect (Molnár, 2013).

Figures 5 and 6 show the link between PD and BD, $\mathrm{PD}$ and IR, respectively. As expected, the confidence ellipse of Figure 5 clearly displays a positive association between these two series, while Figure 6 confidence ellipse does not show a clear relationship between them.
Figures 7 and 8 illustrate the relationship between PD and RGDP, PD and GE, respectively. The confidence ellipse of Figures 7 and 8 clearly shows that as expected, PD decline as RGDP increases, while PD rises as GE increases.

Finally, Figures 9 and 10 show the negative correlation between PD and CPI, PD and EXR, respectively. That is, public debt decreases as inflation rises and exchange rate depreciates.

Table 1: The results of ADF and PP unit root test (intercept only)

\begin{tabular}{crcr}
\hline & Variables & ADF & PP \\
\hline Log & PD & 0.595 & 0.525 \\
BD & $0.057^{*}$ & $0.057^{*}$ \\
TRID & 0.428 & 0.366 \\
TRD & 0.114 & 0.114 \\
RGDP & 0.907 & 0.909 \\
CPI & $0.078^{*}$ & $0.078^{*}$ \\
GE & 0.704 & 0.809 \\
Log of 1st & EXR & 0.727 & 0.739 \\
Pifference & PD & $0.002^{* * *}$ & $0.002^{* * *}$ \\
BD & $0.000^{* * *}$ & $0.000^{* * *}$ \\
& TRID & $0.002^{* * *}$ & $0.002^{* * *}$ \\
TRD & $0.000^{* * *}$ & $0.000^{* * *}$ \\
RGDP & $0.005^{* * *}$ & $0.005^{* * *}$ \\
Level & $0.013^{* *}$ & $0.013^{* *}$ \\
& GE & $0.000^{* * *}$ & $0.000^{* * *}$ \\
EXR & $0.000^{* * *}$ & $0.000^{* * *}$ \\
LIR & $0.041^{* * *}$ & $0.042^{* *}$ \\
\hline
\end{tabular}

Source: Authors' calculation based on CBSL and WB data

Note: Probability values are given in the table. ${ }^{*},{ }^{* *},{ }^{* * *}$ represent the significant at $10 \%, 5 \%$ and $1 \%$ level of significant respectively.

Table 2: Results of Unrestricted Cointegration Rank Test (Trace)

\begin{tabular}{|c|c|c|c|c|}
\hline Null Hypothesis & Alternative Hypothesis & Test Statistic & Critical Value (5\%) & Probability \\
\hline $\mathrm{H}_{0}: \mathrm{r}=0$ & $\mathrm{H}_{1}: \mathrm{r}=1$ & 375.60 & 197.37 & $0.000^{*}$ \\
\hline $\mathrm{H}_{0}: \mathrm{r}=1$ & $\mathrm{H}_{1}: \mathrm{r}=2$ & 272.28 & 159.52 & $0.000^{*}$ \\
\hline $\mathrm{H}_{0}: \mathrm{r}=2$ & $\mathrm{H}_{1}: \mathrm{r}=3$ & 188.07 & 125.61 & $0.000^{*}$ \\
\hline $\mathrm{H}_{0}: \mathrm{r}=3$ & $\mathrm{H}_{1}: \mathrm{r}=4$ & 122.82 & 95.753 & $0.000^{*}$ \\
\hline $\mathrm{H}_{0}: \mathrm{r}=4$ & $\mathrm{H}_{1}: \mathrm{r}=5$ & 78.537 & 69.818 & $0.008^{*}$ \\
\hline $\mathrm{H}_{0}: \mathrm{r}=5$ & $\mathrm{H}_{1}: \mathrm{r}=6$ & 47.311 & 47.816 & 0.056 \\
\hline $\mathrm{H}_{0}: \mathrm{r}=6$ & $\mathrm{H}_{1}: \mathrm{r}=7$ & 30.128 & 29.797 & $0.045^{*}$ \\
\hline $\mathrm{H}_{0}: \mathrm{r}=7$ & $\mathrm{H}_{1}: \mathrm{r}=8$ & 18.818 & 15.494 & $0.015^{*}$ \\
\hline $\mathrm{H}_{0}: \mathrm{r}=8$ & $\mathrm{H}_{1}: \mathrm{r}=9$ & 8.2723 & 3.8414 & $0.004^{*}$ \\
\hline
\end{tabular}

Source: Authors' calculation based on CBSL and WB data

Note: * indicates the rejection of null hypothesis 
Table 3: The Results of Long run Relationship (Dependent variable: LNPD)

\begin{tabular}{lccccccc}
\hline LNRGDP & LNGE & LNTRD & LNTRID & LNCPI & LNBD & LIR & LNEXR \\
\hline$-0.762^{* * * *}$ & $0.207^{* * *}$ & $-0.749^{* * *}$ & $-0.363^{* * *}$ & $-0.948^{* * *}$ & $0.332^{* * *}$ & $0.004^{* * *}$ & $1.124^{* * *}$ \\
$(-7.716)$ & $(4.246)$ & $(-15.10)$ & $(-7.950)$ & $(12.13)$ & $(9.828)$ & $(3.715)$ & $(20.14)$ \\
\hline
\end{tabular}

Source: Authors' calculation

Note: Test statistics are given in the parenthesis. ${ }^{*},{ }^{* *},{ }^{* * *}$ represent the significant at $10 \%, 5 \%$ and $1 \%$ level of significant, respectively.

Table 4: The Results of Long-run Adjustment part of ECM

\begin{tabular}{|c|c|c|c|c|c|c|c|c|c|}
\hline ECT & $\mathrm{D}(\ln \mathrm{PD})$ & $\mathrm{D}(\ln \mathrm{TRD})$ & $\mathrm{D}(\ln \mathrm{TRID})$ & $\mathrm{D}(\ln R G D P)$ & $\mathrm{D}(\ln \mathrm{BD})$ & $\mathrm{D}(\ln \mathrm{CPI})$ & $\mathrm{D}(\ln \mathrm{GE})$ & $\mathrm{D}(\mathrm{LIR})$ & $\mathrm{D}(\ln \mathrm{EXR})$ \\
\hline \multirow[t]{2}{*}{ CointEq1 } & -0.1375 & 0.1635 & 0.0171 & -0.0661 & -0.5141 & 0.1239 & -0.1947 & 0.055 & -0.076 \\
\hline & $(-0.441)$ & $(1.481)$ & $(0.277)$ & $(-0.836)$ & $(-2.98)$ & $(0.335)$ & $(-1.47)$ & $(0.484)$ & $(-0.231)$ \\
\hline
\end{tabular}

Source: Authors' calculation based on CBSL and WB data

Note: Test statistics are given in the parenthesis. ECT represents the error correction term.

\section{Econometric analysis}

The results of ADF and PP unit root test are given in Table 1. Both unit root test approaches confirm that all the variables except LIR are non-stationary in level form (i.e. in logarithm), whereas all of them became stationary at their first difference in both techniques. Since lending interest rate (LIR) is already in percentage and stationary in level which is consistent with other variables. Thus, all the series are integrated in order one [I(1)] according to both methods. Thus, Johansen cointegration technique is adopted to examine the long run relationship between the series.

All the lag length selection criteria suggested to use one lag as an optimal lag. Hence, one lag is included in the model. The results of Johansen and Juselius cointegration test are presented in Table 2.

According to the above results the null hypothesis at rank $0,1,2,3$ and 4 are rejected at $5 \%$ level of significance. Thus, trace statistics identified five cointegrating relationship between the variables under this study. This indicates that the existence of long-run correlation between the variables. The long run results are given in Table 3 .

As expected in theory and some of the existing empirical studies, real GDP (e.g., Sinha et al., 2011; Coenen et al., 2008), direct tax revenue (e.g., Princen \& Mourre, 2013; Coenen et al., 2008), and indirect tax revenue (e.g., Princen \& Mourre, 2013; Coenen et al., 2008) have statistically significant, negative impacts on public debt in the long run; an increase in lnRGDP, $\operatorname{lnTRD}$ and $\operatorname{lnTRID}$ will reduces the $\operatorname{lnPD}$ in the long run. Further, there is a greater possibility for direct tax to contribute more than the indirect tax for the public debt reduction. That is, when other things being constant, if direct tax increase by $1 \%$, then the public debt will decrease by $0.749 \%$, while when the indirect tax revenue increase by $1 \%$, then the public debt will decline only by $0.363 \%$. This implies that tax policy reforms are needed to Sri Lanka for the revenue-based fiscal consolidation. The estimation results can be justifiable theoretically as well as empirically. In short, indirect taxes which consist of about $80 \%$ of total tax revenue in Sri Lanka is inherently regressive. The simple reason is that the persistent high income inequality prevail in Sri Lanka over last 4 decades would not provide any justification for increasing indirect taxes for revenue-based fiscal consolidation. Hence increasing indirect taxes will further reduce disposable income of people so that consumption is reduced, as a result private investment reduction and contractionary effect on output will have a negative impact on tax revenues over the medium term. Along this line of thinking, for example, suggestion to change the tax composition of direct and indirect taxes from 20:80 to 40:60 to make it an equitable tax system in line with other peer countries is seemingly a correct and feasible policy measure and also the recent tax reforms that decreased the VAT from $15 \%$ to $8 \%$ in order to have an economic expansionary effect are evidence to support this argument.

In the same line of argument, the estimation results can be justifiable from theoretical perspectives as well. For instance, indirect tax may change consumer behavior and then distorts economic decisions. Hence there is a greater possibility to create excess burden; a loss of welfare above and beyond the tax revenue actually collected. According to the equivalent variation, greater welfare loss can be eliminated by means of a direct tax 
as it does not change the relative prices of goods. But in the case of indirect taxes the change in relative prices can create inefficiency and thereby, composition of the commodity bundle is distorted resulting lowers individual utility more than necessary (Rosen \& Gayer, 2008: pp. 337-338). The final outcome of all these negative effects of indirect taxes will have an adverse impact on GDP and economic growth which is not desirable for revenue-based fiscal consolidation. Therefore, to avoid concentration of excess income that would not guarantee reinvestment will not contribute to economic expansion, hence develop the tax administration, widen the income tax base and improve efficiency as well as rationalization of tax system to make use of potentials and feasibility for tax revenues from direct taxes. This way of raising tax revenue would hardly have any excess burden and thus have no adverse impact on economic growth, instead progress with revenue mobilisation can help safeguard important social and infrastructure spending (IMF, 2018: p. 3). Therefore, the above explanations provide a reasonable justification as to why direct tax reforms are better than indirect taxation in reducing government debt.

Moreover, government expenditure (e.g., Sinha et al., 2011; Coenen et al., 2008; Alesina \& Tabellini, 1990; Persson \& Svensson, 1990), budget deficit (e.g., Thornton, 2012; Sinha et al., 2011; Garcia, 1998), lending interest rate (e.g., Sinha et al., 2011) and exchange rate have a statistically significant positive impact on public debt in the long run as expected and as in some of the existing literature. That is, raise in all these variable increases the public debt in the long run when other things being constant. But, as oppose to theory and some of the existing literature (e.g., Sinha et al., 2011), consumer price index has a significant negative impact on public debt. During the high inflation period, if the government borrows money from external sources to finance the deficit, the government has to repay more on the future with debt service payment which will make government more burdened in the future. Thus, government may try to get fewer loans and manage to spend within the budget. This could be the reason that public debt decreases as inflation increases.

Next, the long-run adjustment part of the results of ECM is given in Table 4. As expected, speed of adjustment coefficient of public debt (dependent variable) is negative $(0.1375)$ which implies that shortrun disequilibrium that arises from exogenous shocks is corrected by $13.75 \%$ in each year one period after the exogenous shocks. That is one period after the exogenous shocks the variable move backwards towards steady state line with the speed of $13.75 \%$ in each year. However, this coefficient is not statistically significant. Even though, speed of adjustment coefficient of $\operatorname{lnTRD}$, lnTRID, InCPI and LIR are as expected which are not statistically significant. This indicates that there is no significant long run adjustment between $\ln \mathrm{PD}$ and each of these variables. Further, negative and insignificant coefficients of $\operatorname{lnRGDP}, \operatorname{lnGE}$ and $\operatorname{lnEXR}$ indicate that there is no long-run adjustment between $\operatorname{lnPD}$ and each

Table 5: The Results of Short run Dynamic Relationship (Dependent variable: $\Delta$ )

\begin{tabular}{lcc}
\hline Variables & \multicolumn{3}{r}{ Coefficients } \\
\hline$\Delta(\operatorname{lnPD}(-1))$ & 0.1645 & $(0.859)$ \\
$\Delta(\operatorname{lnTRD}(-1))$ & $-0.1390^{* *}$ & $(-1.981)$ \\
$\Delta(\operatorname{lnTRID}(-1))$ & -0.0219 & $(-0.211)$ \\
$\Delta(\operatorname{lnRGDP}(-1))$ & -0.1733 & $(-0.606)$ \\
$\Delta(\operatorname{lnBD}(-1))$ & 0.0487 & $(-0.392)$ \\
$\Delta(\operatorname{lnCPI}(-1))$ & 0.1826 & $(0.719)$ \\
$\Delta(\operatorname{lnNGE}(-1))$ & 0.1943 & $(0.894)$ \\
$\Delta(\operatorname{LIR}(-1))$ & -0.0039 & $(-0.070)$ \\
$\Delta(\ln E X R(-1))$ & $0.1426^{* *}$ & $(2.219)$ \\
\hline
\end{tabular}

Source: Authors' calculation based on CBSL and WB data

Note: Test statistics are given in the parenthesis. ${ }^{*},{ }^{* *},{ }^{* * *}$ represent the significant at $10 \%, 5 \%$ and $1 \%$ level of significant, respectively 
of these variables whereas disequilibrium further move away from that between $\operatorname{lnPD}$ and $\ln \mathrm{BD}$ since the speed of adjustment coefficient of this variable is significant and negative, which implies that due to exogenous shock, public debt increases when the budget deficit rises.

Next, the short-run relationship part of ECM results is given in Table 5. As expected, real GDP, direct tax revenue, indirect tax revenue and lending interest rate have negative impact on public debt in the short run. That is an increase in lnRGDP, lnTRD, lnTRID and LIR will reduce the lnPD in the short run. Further, direct tax contributes more than the indirect tax for the public debt reduction. That is, when other things being constant, if direct tax increase by $1 \%$, then the public debt will decrease by $0.139 \%$ while when the indirect tax increase by $1 \%$, then the public debt will decline only by $0.0219 \%$. This implies that as it has been describe above sections, direct tax reforms do better than indirect tax in reducing the debt level. Hence, tax policy reform is needed to focus more on widening tax base and streamlining the direct tax system with best practices attribution to various tax exemptions, tax avoidance and weaknesses in tax administration to utilise the potentials and feasibility to realise revenue based fiscal consolidation. Moreover, government expenditure, consumer price index, budget deficit and exchange rate have a positive impact on public debt in the short run as expected and as in some of the existing literature. That is, rise in all these variables increase the public debt in the short run when other factors are constant. But the effect of these variables, except exchange rate, on debt to GDP ratio is not statistically significant. This result indicates that tax revenue and exchange rate play a crucial role on public debt in the short run than the other factors.

Next, the causality relationship between the variables is given in Table 6. Granger causality test identified unidirectional causality relationship between direct tax revenue and public debt (stemming from $\operatorname{lnTRD}$ to $\ln \mathrm{PD}$ ), indirect tax revenue and real GDP (stemming from $\operatorname{lnTRID}$ to $\ln R G D P$ ) and inflation and indirect direct tax revenue (that stemming from $\operatorname{lnCPI}$ to $\operatorname{lnTRD}$ ) at $5 \%$ level of significance. Moreover, weakly significant and unidirectional causality relationship was found between government expenditure and public debt (stemming from $\operatorname{lnGE}$ to $\ln P D$ ) and inflation and tax revenue (stemming from $\operatorname{lnCPI}$ to $\operatorname{lnTRD}$ ). Further, real GDP is weakly and unilaterally correlated with direct tax revenue, indirect tax revenue and exchange rate in the long run.

\section{CONCLUSIONS AND POLICY RECOMMENDATION}

This study used annual data of Sri Lanka over the period of 1990-2019 to examine the relationship between public debt, budget deficit and tax policy reform for fiscal consolidation. The estimation results of both Johansen cointegration model and Error correction model suggest

Table 6: Results of VECM Granger Causality/Block Exogeneity Wald test

\begin{tabular}{lcl}
\hline Null Hypothesis & Probability value & Decision \\
\hline DLNGE does not Granger Causes DLNPD & $0.088^{*}$ & Reject $\mathrm{H}_{0}(10 \%)$ \\
DLNTRD does not Granger Causes DLNPD & $0.009^{* * *}$ & Reject $\mathrm{H}_{0}$ \\
DLNTRID does not Granger Causes DLNPD & $0.072^{*}$ & Reject $\mathrm{H}_{0}(10 \%)$ \\
DLNRGDP does not Granger Causes DLNTRD & $0.084^{*}$ & Reject $\mathrm{H}_{0}(10 \%)$ \\
DLNTRID does not Granger Causes DLNRGDP & $0.043^{* *}$ & Reject $\mathrm{H}_{0}$ \\
DLNRGDP does not Granger Causes DLNTRID & $0.071^{*}$ & Reject $\mathrm{H}_{0}(10 \%)$ \\
DLNRGDP does not Granger Causes DLNEXR & $0.079^{*}$ & Reject $\mathrm{H}_{0}(10 \%)$ \\
DLNCPI does not Granger Causes DLNTRD & $0.086^{*}$ & Reject $\mathrm{H}_{0}(10 \%)$ \\
DLNCPI does not Granger Causes DLNTRID & $0.000^{* * *}$ & Reject $\mathrm{H}_{0}$ \\
\hline
\end{tabular}

Source: Authors' calculation based on CBSL and WB data

Note: Since there are 9 variables, there are 36 pairs ( 72 cases) of causality relationships when all of these results are included, which are not statistically significant. Only the results of significant causality relationships between the variables are given in the table.

The probability values are given in the parenthesis. ${ }^{*},{ }^{* *},{ }^{* * *}$ show that variables are significant at $10 \%, 5 \%$ and $1 \%$ level of significant respectively. 
that direct tax revenue affect the public debt negatively and significantly, whereas, exchange rate affects public debt positively and significantly both in the long run and short run. But, indirect tax revenue, and real GDP are negatively and significantly correlated with central government debt to GDP ratio only in the long run, while these two variables do not have significant impact on public debt in the short run, even though effect of these variables is as expected by theory and some of the existing studies.

Moreover, government expenditure and budget deficit have positive impact on central government debt to GDP ratio, both in the long run as well as in the short run. But the short run relationship is not statistically significant. In contrast, lending interest rate affects public debt positively in the long run, while negatively in the short run. Nevertheless, short run impact is not statistically significant. At the same time, impact of inflation on public debt is negative and statistically significant in the long run, while positive and not statistically significant in the short run. Moreover, there is no long run adjustment in public debt due to exogenous shocks since the speed of adjustment coefficient of this variable is not statistically significant.

This study identified that government expenditure, tax revenue and indirect tax revenue cause public debt, whereas GDP causes direct tax revenue, indirect tax revenue and exchange rate. Also, inflation causes direct and indirect tax revenue while indirect tax revenue causes real GDP.

This implies that, there is a causality relationship between fiscal policy variables and public debt. Thus, direct and indirect tax revenue and exchange rate play an important role in determining public debt both in the short run as well as in the long run. It is evident that the complexity of the tax system with anomalies has distorted the potentials for increasing buoyancy of tax revenues over many decades in the past. Also indirect taxes are regressive and further increasing of indirect taxes would not be feasible due persistent high income inequality and possible adverse impact on economic growth. Therefore, the findings of this study suggest that there need to be appropriate tax policy reforms in Sri Lanka since direct tax can contribute more than the indirect tax for public debt reduction both in the short run and in the long run for the fiscal consolidation.

\section{END NOTES}

1. Availability of data for some selected variables (specially, data of direct and indirect tax revenue) and a reasonable period to observe the dynamics of debt accumulation process made the authors to consider this period in the sample.

2. Direct and indirect tax were used separately to see which tax system is effective in the smooth running of the economy, minimising burden to the public.

3. Even though logarithm for LIR was not taken, this variable was included in the vector of $\ln \mathrm{Y}_{\mathrm{t}}$ and matrices of $\ln \mathrm{Y}_{\mathrm{t}-i}$ for the sake of consistency and to make ECM model convenient.

\section{REFERENCES}

Alesina, A. \& Tabellini, G. (1990) A positive theory of fiscal deficits and government debt, The Review of Economic Studies, 57(3), pp: 403-414.

DOI: https://doi.org/10.2307/2298021

Alesina, A., Barbiero, O., Favero, C., Giavazzi, F. \& Paradisi, M. (2017) The effects of fiscal consolidations: Theory and evidence (No. w23385), NBER Working Paper Series, Cambridge, Massachusetts, USA: National Bureau of Economic Research.

DOI: https://doi.org/10.3386/W23385

Ardagna, S. (2001) Fiscal policy composition, public debt, and economic activity, Public Choice, 109(3), pp: 301-325.

DOI: https://doi.org/10.1023/A:1013021004195

Beetsma, R. M., Furtuna, O. \& Giuliodori, M. (2018) Revenue versus Spending-Based Consolidation Plans: The Role of Follow-Up, ECB Working Paper Series No 2178 / September 2018, Frankfurt: European Central Bank.

Checherita, C. \& Rother, P. (2010) The impact of high and growing government debt on economic growth: An empirical investigation for the Euro area, Working paper series No.1237/ August 2010, Frankfurt: European Central Bank.

Coenen, G., Mohr, M. \& Straub, R. (2008) Fiscal consolidation in the euro area: Long-run benefits and short-run costs, Economic Modelling, 25(5), pp: 912-932.

DOI: https://doi.org/10.1016/j.econmod.2007.11.011

Coomaraswamy, I. (2017) Revenue Based Fiscal Consolidation Towards Sustainable Growth [Online] $19^{\text {th }}$ January, $21^{\text {st }}$ Annual Tax Oration, Institute of Chartered Accountants of Sri Lanka, Available from: https://www.casrilanka.com/casl/images/ stories/2017/2017_pdfs/full_text_of_oration_by_central_ bank_governor.pdf [Accessed: 13 ${ }^{\text {th }}$ November 2019].

Garcia, F. (1998) Public Debt Sustainability and Demand for Monetary Base, IMF Working Papers.

International Monetary Fund (IMF) (2018) IMF Country 
Report: Sri Lanka Selected Issues, Washington, D. C: International Monetary Fund.

Kumarasiri, K., Weerasekara, R. L., Ranaweera, C. \& Liyanaarachchi, T. (2019) Revenue based fiscal consolidation and economic growth in Sri Lanka, Working paper No. economics: 201904. 2019, Queensland, Australia: Griffith University.

Lopes da Veiga, J. A., Ferreira-Lopes, A. \& Sequeira, T. N. (2016) Public Debt, Economic Growth and Inflation in African Economies, South African Journal of Economics, 84(2), pp: 294-322.

DOI: https://doi.org/10.1111/saje.12104

Molnár, M. (2013) Fiscal consolidation: What factors determine the success of consolidation efforts?, OECD Journal: Economic Studies, 2012(1), pp: 123-149.

DOI: https://doi.org/10.1787/eco_studies-2012-5k8zs3twgmjc

OECD (2011) Fiscal consolidation: targets, plans and measures, OECD Journal on Budgeting, 2011(2).

DOI: https://doi.org/10.1787/budget-11-5kg869h4w5f6

Persson, T. \& Svensson, L. E. (1989) Why a stubborn conservative would run a deficit: Policy with time-inconsistent preferences, The Quarterly Journal of Economics, 104(2), pp: 325-345.

DOI: https://doi.org/10.2307/2937850

Princen, S. \& Mourre, G. (2013) The role of tax policy in times of fiscal consolidation (No. 502), Brussels: Directorate General Economic and Financial Affairs (DG ECFIN), European Commission.

Rosen, H. S. \& Gayer, T. (2008) Public Finance, $6^{\text {th }}$ Edition, New York: McGraw Hill.

Sinha, P., Arora, V. \& Bansal, V. (2011) Determinants of Public
Debt for Middle Income and High Income Group Countries Using Panel Data Regression (No. 32079), Munich Personal RePEc Archive (MPRA).

Sri Lanka, Central Bank of Sri Lanka (2019) Annual Report 2019, Colombo: Central Bank of Sri Lanka.

Sri Lanka, Central Bank of Sri Lanka (2017) Annual Report 2017, Colombo: Central Bank of Sri Lanka.

Swati, J. (2019) Responsiveness of fiscal consolidation towards long term growth in India and Sri Lanka, Sri Lanka Journal of Business Economics, 8(1), pp: 1-23.

Thornton, D. L. (2012) The US deficit/debt problem: a longer-run perspective, Federal Reserve Bank of St. Louis Review, 94(6), pp: 441-455.

DOI: https://doi.org/10.20955/r.94.441-456

Tsibouris, G. C., Horton, M. A., Flanagan, M. J. \& Maliszewski, W. S. (2006) Experience with large fiscal adjustments, Occasional paper No. 246, Washington D. C.: International Monetary Fund.

Uctum, M. \& Wickens, M. (2000) Debt and Deficit Ceilings, and Sustainability of Fiscal Policies: an Intertemporal Analysis, Oxford Bulletin of Economics and Statistics, 62(2), pp: 197222.

DOI: https://doi.org/10.1111/1468-0084.00168

Van Bon, N. (2015) The relationship between public debt and inflation in developing countries: Empirical evidence based on difference panel GMM, Asian Journal of Empirical Research, 5(9), pp: 128-142. 